\title{
Steering innovations towards a green economy: understanding government intervention
}

\author{
N. Droste ${ }^{1}$, B. Hansjürgens ${ }^{1}$, P. Kuikman ${ }^{2}$, N. Otter ${ }^{3}$, R. Antikainen ${ }^{4}$, P. Leskinen ${ }^{4}$, K. Pitkänen ${ }^{4}$, L. \\ Saikku' ${ }^{4}$ E. Loiseau ${ }^{5}, M$. Thomsen $^{6}$ \\ ${ }^{1}$ UFZ - Helmholtz Centre for Environmental Research, Permoserstr. 15, 04318 Leipzig, Germany; nils.droste@ufz.de \\ ${ }^{2}$ Alterra, Wageningen University, Droevendaalsesteeg, 6708 PB Wageningen, Netherlands \\ ${ }^{3}$ Carinthia University of Applied Sciences, Europastraße 4, A-9524 Villach, Austria \\ ${ }^{4}$ Finnish Environment Institute, SYKE, P.O. Box 140, 00251 Helsinki, Finland \\ ${ }^{5}$ Irstea, 361, rue Jean-François Breton, BP-5095, 34196 Montpellier Cedex 5, France \\ ${ }^{6}$ Aarhus University, Frederiksborgvej 399, 4000 Roskild, Denmark
}

\begin{abstract}
:
In this paper we analyse institutional conditions facilitating the transition towards a green economy by encouraging investment in the enhancement of natural capital and social equity, focusing especially on government interventions. Presenting a conceptual institutional model how innovation generally occurs, we depict system levels that can be influenced by government interventions to facilitate societal innovations towards a green economy. We hypothesize that the transition to a green economy is about extending the possibility frontier outwards towards a greener economy while at the same time limiting the "action space" at the brown economy end; a normative evaluation framework is presented to assess transitions correspondingly. We elaborate on the emerging lessons for governance by examining evidence from five selected European case studies, and provide a non-exhaustive list of impacts that government intervention may have on the action spaces available at different system levels.
\end{abstract}

Keywords: governance, green economy, innovation, natural capital, social equity, transition management

Highlights:

- We propose a systemic innovation approach to explain paths towards a green economy.

- We show how green economy transitions are shaped by governance intervention.

- We provide case study evidence from five European countries.

Word count: 8564 words, two figures 
Author-produced version of the article published in Journal of Cleaner Production, 2016, N¹35, p.426-434

The original publication is available at http://www.sciencedirect.com

Doi: 10.1016/j.jclepro.2016.06.123

\section{A green economy vision}

Twenty years after the Rio conference on sustainable development, greening the economy has been promoted as a new strategy for enhancing human well-being and reducing environmental risk (Barbier and Markandya, 2013; Pearce et al. 1989). It is seen as a way to implement sustainable development, amplifying the Agenda 21 (UNEP, 2011: foreword). This vision is generally shared: it was adopted at the Rio+20 meeting as part of "the future we want" (UN, 2012), it has been operationalized within the Sustainable Development Goals and their indicators (UN, 2015), and it relates essentially to mulitlateralmultilateral agreements such as the climate, biodiversity and desertification conventions. Two investment areas constitute key elements of a green economy: enhancing (i) natural capital, that is, stocks of and flows from agriculture, fisheries, water bodies and forests, and (ii) energy and resource efficiency, that is, enabling environmental technology in renewable energy, manufacturing, waste management, buildings, transport, tourism and cities (UNEP, 2011). Such focus on investments is justified because "investments shape the future of our economies. Investment decisions choose one type of infrastructure over others, another type of production or technology over others, which narrows down the options for future choices" (UNEP, 2014a, p. 2). Thus, transforming the economy is understood to be about choices between different development paths - a far from trivial matter, considering the scale of the challenges and the changes envisaged. Any economic strategy will require investments, but the normative green economy vision needs both private and public investment to be steered towards greener and fairer strategies. It is therefore recognized that such investments have to be "supported by targeted public expenditure, policy reforms and regulation changes" (UNEP, 2011, p. 16) - which stresses the role of government intervention.

Reducing environmental harm and social inequality while growing the economy requires a transformation of existing production and consumption patterns and thus transformations of the entire economy (Allen, 2012; UNEP, 2014a). The green economy perspective thereby focuses on the fundamental origin of environmental degradation - namely, the way the economy currently works. In doing so, it may offer solutions that turn out to be relatively robust against potential setbacks such as rebound effects. Furthermore, it is a macro-economic approach that, as such, may serve to promote overarching policies rather than fragmented ones ${ }^{1}$. Its beneficial aspects notwithstanding, the green economy approach entails certain political difficulties with regard to implementation (Barbier, 2012) as well as high transaction costs (Barbier, 2011). Most importantly, transforming the economy requires innovation in terms of available technology, organizational support, market conditions, the broader societal setting, and the overarching governance framework (Barbier, 2011; UNEP, 2011).

In this paper, we analyse the governance system that may facilitate such innovation and a transition to a green economy, putting a particular emphasis on government interventions. Our research question is: How can governance measures support innovations aimed at transitioning towards a green economy? To this end, we develop a refined model of innovation based on a review of the existing innovation literature and propose a normative evaluation framework to assess the transformative effect of an innovation (section 2). Analysing particular measures within the continuum of innovation stimulating mechanisms, we focus on the role of the state in enabling the transition to a green economy and illustrate it with evidence from five selected European case

\footnotetext{
${ }^{1}$ One of the most far-reaching political implementations regarding a transition towards a green economy is the EU circular economy strategy (EU 2015).
} 
studies (section 3). In Section 4 we discuss our findings and conclude by reviewing the remaining knowledge gaps.

\section{The transition towards a green economy from a theoretical perspective: conceptualizing innovation processes and proposing an evaluation framework}

Technological innovations are a crucial component of a green economy transition ${ }^{2}$, but ultimately, such a transition can only be achieved through societal innovation, which has been defined as "a novel economic and/or social improvement to people's everyday life [...bringing] a (radical or incremental) systemic change to society's structures or modes of operation, and is legitimated by the majority of societal stakeholders" (Lehtola and Ståhle, 2014, p. 172). Two aspects of this definition are particularly striking: i) societal innovation changes the system and ii) it benefits people. On the basis of this understanding, we hypothesize that any intentional system change (e.g. towards a green economy) will require some kind of societal innovation. The question of how such innovation can be fostered in a market economy is vital to understand how a green economy transition can be facilitated.

One particular (collective) actor who has both ability and legitimacy to steer such innovation towards sustainability is the government. ${ }^{3}$ It can set standards and regulation, create the respective instrument policy mixes, and can thus sanction and incentivize behaviour of private actors - who do not necessarily have an intrinsic motivation to contribute to a public good of sustainability transitions (Geels, 2011). While there is a broad body of literature about firm and niche innovations that may eventually change the system on a broader scale, analyses of politics and the role of government in societal innovations are relatively scarce (as notable exceptions see Borrás and Edquist 2013; Flanagan et al. 2011; Geels, 2014; Loorbach, 2010; Smith, 2000; Voß et al., 2009). Thus, we aim to contribute to the literature by i) refining and extending an innovation governance framework based on Röpke (1977) in which we locate government intervention, and ii) proposing a basic, twodimensional assessment framework which can measure the transformative effect of green economy innovations.

\subsection{Innovations for a green economy and the role of governance}

Societal innovation or regime shifts are keys to turn existing economies into a green economy. To clarify at which levels such social innovations may occur and take effect we present a stylized conceptual model in which different systems types and levels of institutions are ordered hierarchically (see Figure 1). The model is based on an older systemic innovation approach developed by Röpke (1977), who adopts a Schumpeterian perspective on entrepreneurial behaviour,

\footnotetext{
${ }^{2}$ In the transition management literature, transformation refers to a "wholesale shift in the economic mode of production" and transition to an "iterative, incremental change towards uncertain futures" (Brown et al., 2012, p. 1608 f.). In this paper we do not refer systematically to these differences, preferring to use the term rather interchangeably: if a transition is steered appropriately, it may eventually become a transformation (cf. Dolata, 2011).

${ }^{3}$ See Cooke (2015, p. 4), who remarks that the "key point regarding governments, and cities particularly in this context, is that they are the main variant to markets as stimulators of change", Scott (2008) who emphasizes that legitimacy stems from cultural support, moral authority or legal sanction, and Edquist (2001, p. 3) who remarked, that a weakness of the technological innovation approach is that "it lacks a 'theoretical' component about the role of the state".
} 
Author-produced version of the article published in Journal of Cleaner Production, 2016, N¹35, p.426-434

The original publication is available at http://www.sciencedirect.com

Doi: 10.1016/j.jclepro.2016.06.123

differentiating between invention, innovation and the diffusion of novel investments in market-type societies (Schumpeter, 1928). Such a system approach has been taken up by several scholars like Lundvall (1992), Freeman (1995) and Edquist (1997), who developed the so-called National Systems of Innovation approach. A national innovation system can be defined as "all important economic, social, political, organizational, and other factors that influence the development, diffusion, and use of innovations" (Edquist, 1997, p. 14). As a consequence, a national system of innovation should be seen as a complex building with one system interacting with the other subsystems. Focussing on the spatial perspective, the term 'regional innovation system' came into use since the 1990s (cf. Cooke, 2015). At its core, the rationale of this research was to address the effects of systematic network relationships for innovation at the regional level (Carlsson, 2005; Uyarra 2010). Such spatial and sectoral levels of technological innovation systems were summarized in a consolidated multi-level framework by Markard and Truffert (2008). Relating the technological innovation perspective with the literature on strategic niche management and transition management, Markard et al. (2012) clarify that socio-technological innovations change user practices and institutional structures and sustainability transitions imply normative goals.

The literature on transition management defines micro (technological) niches, meso level regimes, and macro socio-technological "landscapes" (Geels, 2004). While niches are spaces where actors are "willing to invest in improvements of new technology and the development of new markets" (Hoogma et al., 2002, p. 4), regimes are "practices and associated rules that stabilize existing systems" (Geels, 2011, p. 26), and socio-technological "landscapes" are beyond the "direct influence of actors" and provide "even stronger structuration of activities than regimes" (Geels, 2004, p. 913). While innovation takes place in niches, wider structural changes (as required for a green economy) occur only at regime or landscape level (Geels, 2004; Schot and Geels, 2008; Smith, 2007; Verbong and Geels, 2007) ${ }^{4}$. Transformations can be induced by i) radical novelties at niche level, ii) structural changes of regimes or landscapes, and iii) co-evolutionary processes and interactions (Schot and Geels, 2008).

We, however, start elaborating on a multi-level framework from a microeconomic perspective: In his system innovation approach, Röpke (1977) assumes that a human actor who creates the novelty (invention) is a key and original element. He proposes a behavioural model in which innovative action emerges as a result of i) individual capacities and competencies, ii) the organizational structure in which inventors work, and iii) the market in which an entrepreneur and his/her organization is embedded. We augment the model by adding two further system layers: iv) the system of rules and norms prevailing in societies and economies, which we refer to as the governance system, and $(v)$ the characteristics of and events occurring in the environment.

1) The individual actor seeks to develop and implement novel solutions by reconfiguring known elements into a new pattern (Röpke, 1977, p. 102). This actor is the "inventor" in Schumpeter's sense. The innovation process is based upon individual competencies that entail elements of creativity, originality and intuition (Röpke, 1977) which in turn leads to new products, new organizational structures and/or new societal arrangements. The greater the

\footnotetext{
${ }^{4}$ In the transition management literature, transformation refers to a "wholesale shift in the economic mode of production" and transition to an "iterative, incremental change towards uncertain futures" (Brown et al., 2012, p. 1608 f.). In this paper we do not refer systematically to these differences, preferring to use the term rather interchangeably: if a transition is steered appropriately, it may eventually become a transformation (cf. Dolata, 2011).
} 
Author-produced version of the article published in Journal of Cleaner Production, 2016, N¹35, p.426-434

The original publication is available at http://www.sciencedirect.com

Doi: 10.1016/j.jclepro.2016.06.123

innovation, the greater the uncertainty about potential outcomes and the greater the corresponding risks (ibid. p. 130 ff.). Innovations are therefore dependent on how well the actor is able to cope with such uncertainty and risk. The willingness and ability of entrepreneurs to take individual risks, for instance, is characterized, inter alia, by their environment that is shaped by social norms, legal provisions, organizational or market conditions, the overarching governance system, and - ultimately - by planetary boundaries.

2) Actors are embedded in all kinds of social organization, be they formal ones, such as businesses, or more informal ones, such as networks (Röpke, 1977, p. 177 ff). A division of labour prevails in these organizations, with different actors organizing and selecting options from a complex world in order to reduce uncertainty and risk (ibid.). Power, hierarchies and liberty are manifested to varying degrees in these different organizations, but the outcome in each case is a set of intra-organizational institutions that organize innovative behaviour by enabling or hindering successful individual risk-coping strategies. Depending on how risk averse or risk friendly an organization is, actors may or may not have sufficient space and support for innovative activities. Innovation within an organization requires the allocation (or investment) of sufficient resources to support the innovation. Like in the niche concept, the social organizations are the place where radical innovations take place - although in our model they originate from individual competence and action. As such, organizations are influenced by market relations (e.g. market power, barriers hindering or preventing access to new and emerging markets etc.). Additionally, they are faced with rules and norms that are defined directly by the governance system, including requirements for company constitutions or liability rules.

3) On the next level above organizations is the market system, which is comprised of rule-bound interactions between economic subjects (Röpke, 1977, p. $253 \mathrm{ff}$ ). It is the space where products and services - both tangible and intangible - are exchanged, constituting a mechanism through which resources are allocated. Different types of organization (e.g. in the labour market: businesses, universities, regulatory authorities and civil society associations) compete in their capacity to reduce complexity, absorb uncertainty, produce variety, adapt through social learning and attract innovators. Depending on the market's structure, rules and participants, it may either hinder or facilitate innovations in organizations in which the innovator acts. While in the regime concept of the technological innovation literature is separated into e.g. science, market or technological regimes (cf. Geels 2011), we find it helpful to consider that different organizations from these different regimes interact, collaborate and compete in different markets (e.g. labour, capital, services). The way markets emerge and interact is also determined to a considerable degree by governance rules (market order, regulation with respect production technology, product allowances, patenting, etc.).

4) The market system is regulated by an overarching social governance system, which embodies the rules for itself and all its subsystems. The governance system is one dimension of social innovation (see Swyngedouw, 2005). It defines how societal (market) interaction is structured, what actions are (not) permissible and what kind and quality of organizations are allowed to be formed. The governance system is a decisive element with regard to the feasibility of innovations, not least because it defines and shapes 'the rules of the game' for all other subsystems. These rules are defined and determined (mainly) by the governance system. As we see it, one key actor that defines the governance system itself is the government, given 
Author-produced version of the article published in Journal of Cleaner Production, 2016, N¹35, p.426-434 The original publication is available at http://www.sciencedirect.com

Doi: 10.1016/j.jclepro.2016.06.123

that at least formal rules can be institutionalized through legislative action and many other institutions can be supported or hindered by state intervention (see Smith, 2000).

5) Based on the work of Daly and Farley (2011) and Costanza et al. (2012), we furthermore assume that the entire societal system is a subsystem of system Earth, since all human activity is co-shaped and delimited by the resources available on planet Earth (Rockström et al., 2009; Steffen et al., 2015). The Earth system, however, is different in terms of its anthroprogeneity: the Earth system is primarily characterised by biophysical limits (e.g. absolute finiteness with respect to space, natural resources and ecological sink capacities). Nevertheless, the formal and informal rules that ensure Earth's carrying capacity is properly considered in societal decision making are to be defined in the governance system. This is to say the biophysical carrying capacities of system Earth shape the norms of sustainable behaviour by imposing (natural) limits upon what actions can be sustained in the long run but the norms are man-made.

These system levels may not be separable in every instance. Market mechanisms, for example, constitute institutions in themselves and are closely related to the governance systems that shape them. Furthermore, institutions may originate from the interaction between groups of individuals, while markets may emerge as a result of organizational behaviour. Nevertheless, we see this model as a fruitful conceptual framework that helps us to understand the factors that drive societal innovations and thus pave the way towards a green economy. While there are quite some similarities or at least organizational overlaps, market and governance system levels with the ideas of niches, regimes and landscapes in the innovation systems literature, the two elements that our model explicitly refers to, are a) the individual actor which we based upon Röpke's original work, and b) the planetary system boundaries. We consider both important extensions with regard to the explanatory power about how innovations occur in multi-level systems, i.e. regarding sustainable development.

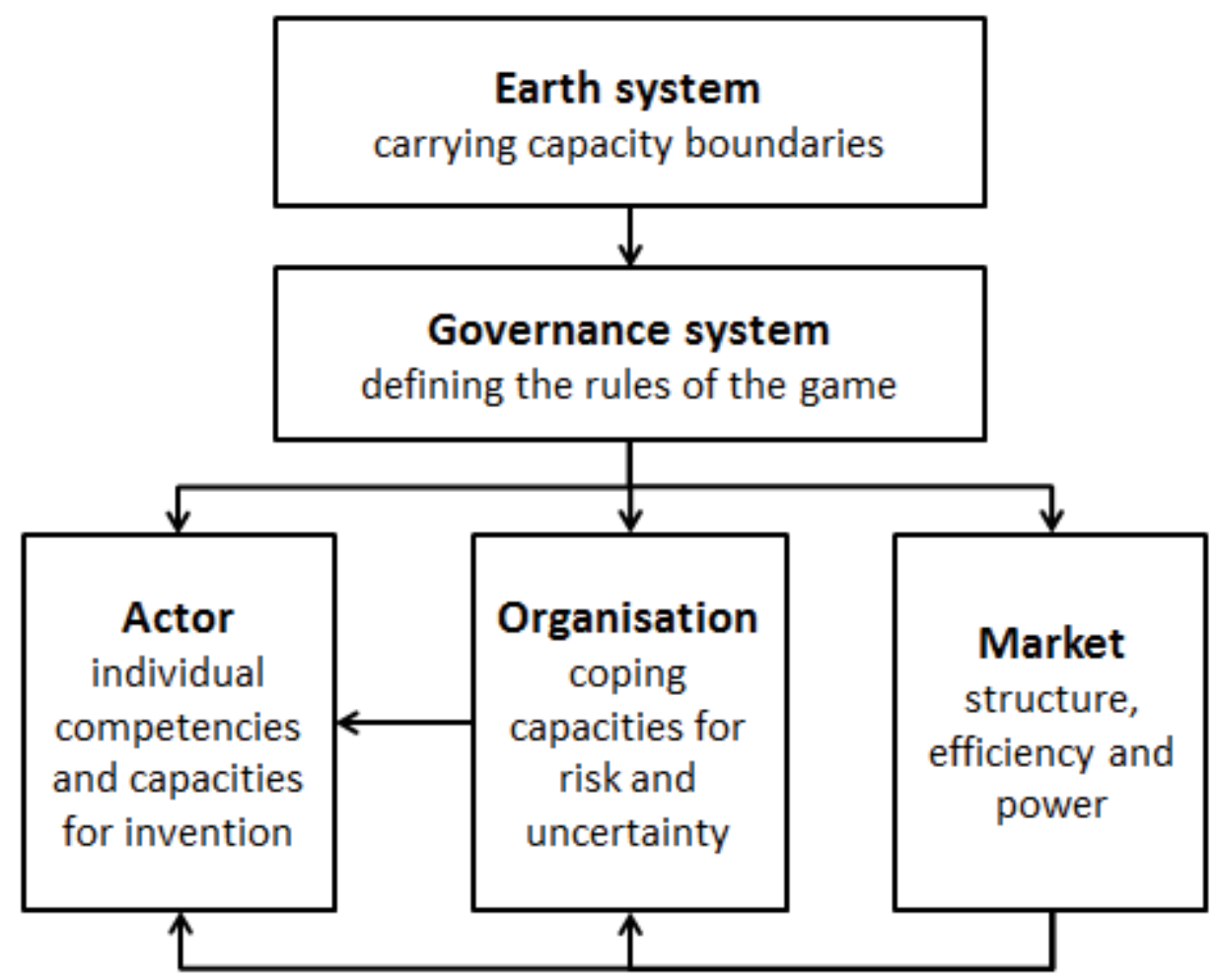

Figure 1: A framework for green economy innovations, based on Röpke (1977) and adapted and extended by the authors. 
Author-produced version of the article published in Journal of Cleaner Production, 2016, N¹35, p.426-434 The original publication is available at http://www.sciencedirect.com Doi: 10.1016/j.jclepro.2016.06.123

Incorporating these different perspectives, we propose a stylized conceptual model consisting of system levels or layers of subsystems that either allow or hinder the emergence of innovations (see Figure 1). We refer to these different system levels as 'action spaces' that contain room for innovation. The actor has an individual space where he/she can train and evolve capabilities to invent, the organisation has a space for collective action to improve risk coping, the market is a space for inter-organisational behaviour, the governance system provides a space to shape the 'rules of the game', and the Earth is where humanity acts (and is restricted) on a global scale. This means that each system level action space has particular boundaries that define what acts are possible and which are not. All together these action spaces' boundaries and opportunities shape and define individual, collective and humanity's action and ability for societal innovation.

\subsection{Governing Green Economy Transitions}

Our focus on green economy transitions incorporates a normative stance towards sustainability. We explicitly focus on government intervention that is meant to steer societies toward improving "human well-being and social equity, while significantly reducing environmental risk and ecological scarcities" (UNEP, 2011, p. 16). Hence, our analytical concept is not only positivist and explanatory but also focuses on particular changes and regime shifts towards a normative position that is inherent in the green economy concept (cf. Loiseau et al. 2016). The two key norms are that any transition towards a green economy must improve both societal and environmental conditions. The concept thus implies a boundary condition: a deterioration of these dimensions is to be prevented. Following our basic conceptual approach that ultimately considers governance systems to be shaping actor-based innovation processes, we propose a two-dimensional framework that can serve to operationalize and measure a successful transition to a green economy.

Proposition 1: A green economy enhances natural capital. For a green economy to exist in the sense defined by UNEP, the degradation of ecosystems and their services must be halted (Barbier, 2011). This requires the enhancement of natural resource stocks through investments in natural capital (UNEP, 2010) and resource efficiency (UNEP, 2011), leading eventually to an absolute decoupling of economic activity and resource depletion.

Proposition 2: A green economy enhances the quality of life within the society concerned. Within a green economy societal equity and human well-being must be improved (Allen, 2012; Costanza et al., 2012; UNEP, 2014a). The green economy is an inclusive economy; hence, policies leading to successful GE transitions will include relevant stakeholders in the formulation of goals as well as in their implementation and monitoring (UNEP, 2011). Furthermore, green economy transitions require (a) visionary actor(s) and bold leadership (Allen, 2012; UNEP, 2014a). In the sense of improving societal equity and human well-being, the success of a green economy transition can be measured by social equity indicators covering factors such as life satisfaction, health, education, working conditions and many others besides.

Having proposed such minimum standards it becomes apparent that only true Pareto improvements (win-win) can facilitate a successful green economy transition. Such a Pareto improvement can be represented by an outward (Northeast) movement within a two-dimensional space measuring societal and environmental progress (Figure 2). Often, however, choices involve trade-offs in which one dimension can only be increased at the expense of the other. In such a case, two conditions must hold: i) substitutability is given, meaning that lost ecosystem services or reduced 
quality of life can be replaced by an increase in the other dimension, and ii) that the loss is actually offset and entirely compensated for ${ }^{5}$.

It should be noted that extending a single action space outwards may not suffice to transform the economy. While new innovations may become feasible due to an intra-organizational action space shift facilitating "greener" innovations of individual 'entrepreneurs', the socio-environmental system nonetheless may have its path dependencies and lock-in effects (and, often, market power), which may pose a barrier to successfully establishing such innovations. We therefore suggest that a successful green economy transition will also restrict the potential action space at the "brown", least social and environmentally friendly end of the economy and serve to remove barriers (Pareto inferior settings and actions). That is to say that the dirtiest and socially most questionable practices in industrialized and industrializing societies are to be removed from the range of potential societal and market interactions. A successful green economy transition therefore requires the action spaces to shift outward across all four system layers up to the governance system - greening and cleaning production and consumption, and thus aligning with the carrying capacities of system Earth. If there is a simultaneous shift at the different system levels, innovations and their facilitating investments are much more likely to result in an improvement of at least one dimension without deteriorating the other.

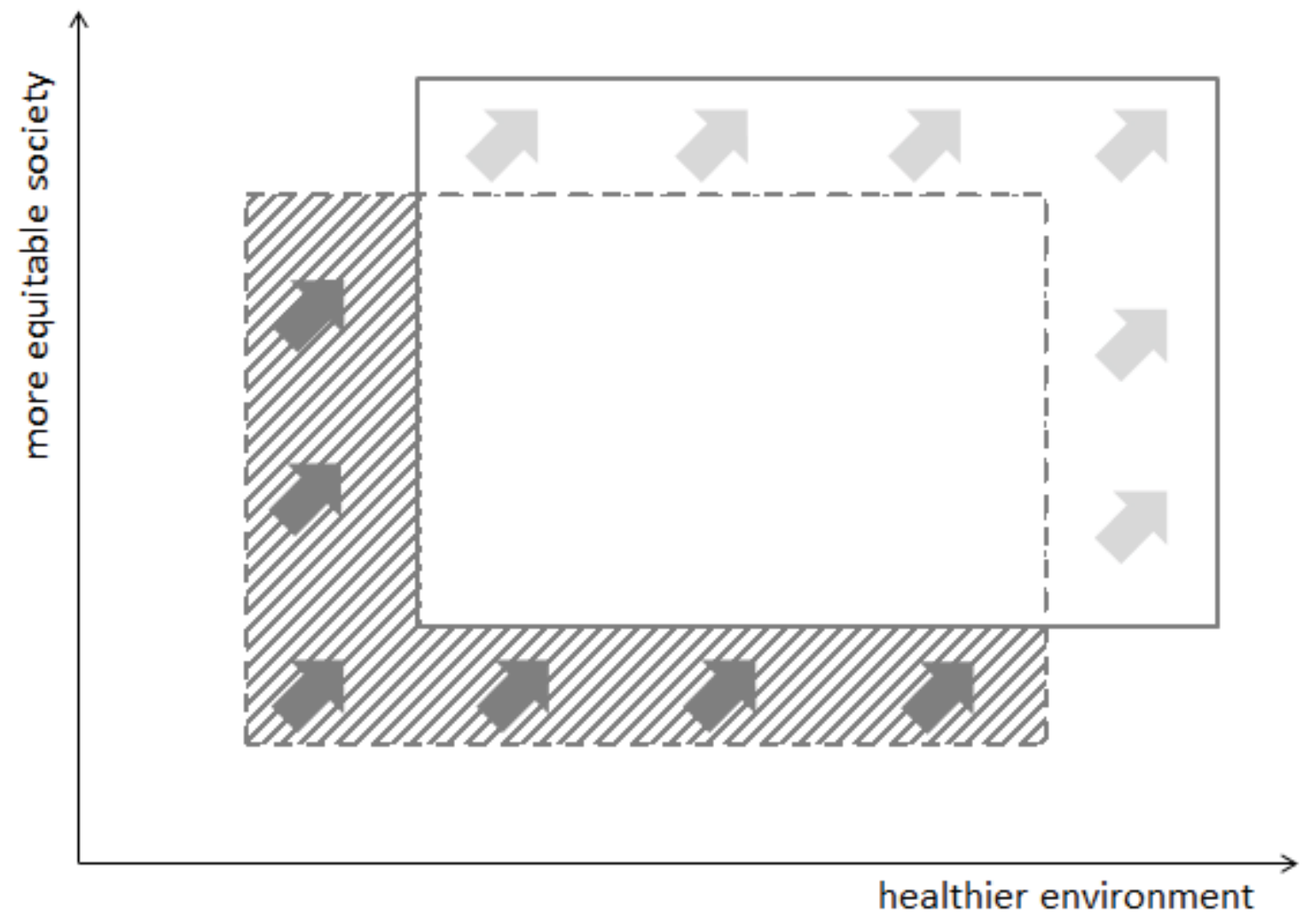

Figure 2: Governing green economy transitions. Source: authors' own representation

\footnotetext{
${ }^{5}$ In this respect, we follow a strong Pareto criterion, which implies that a hypothetical compensation payment (as in a Kaldor-Hicks welfare criterion) is not sufficient for a transition to a green economy.
} 


\section{Analysing government interventions aimed at promoting the transition towards a green economy: five case studies}

Assuming that the governance system plays a decisive role in pulling and pushing economies towards sustainability by defining the rules of the game, we now focus on the role and diversity of government interventions in enabling a greener economy and erecting obstacles to the brown economy along a continuum of possible measures.

\subsection{Data collection and operationalization of constituting elements}

To elaborate on the potential scales of different government interventions, we analyse selected cases from five European countries that vary in their spatio-temporal scope, representing different target sectors and governance mechanisms. For each case we collected data from various sources such as scientific literature, policy documents, project reports, webpages, and summarized the data to derive essential characteristics such as critical success factors (see Pitkänen et al., 2016). We do not aim to generalize particular findings beyond the individual cases but employ our analytical framework to elaborate on how different governance measures can influence case specific opportunities for sustainability innovation and steer transformation towards a green economy. Taking such an approach we aim at generating a context-specific understanding of potential effects of different policy measures.

Table 1: Operationalizing case studies' governance mechanisms and green economy transitions

\begin{tabular}{|c|c|c|}
\hline case study & main governance mechanisms & green economy transition indicators \\
\hline $\begin{array}{l}\text { German } \\
\text { energy } \\
\text { transition }\end{array}$ & $\begin{array}{l}\text { macro-scale government regulation, } \\
\text { changing market structure and setting } \\
\text { incentives }\end{array}$ & $\begin{array}{l}\text { increasing renewable energy and } \\
\text { energy efficiency, ensuring supply } \\
\text { security and affordability }\end{array}$ \\
\hline $\begin{array}{l}\text { Finnish } \\
\text { municipalities' } \\
\text { greenhouse } \\
\text { gas emission } \\
\text { reductions }\end{array}$ & $\begin{array}{l}\text { public procurement and investment, } \\
\text { stimulating private actor participation }\end{array}$ & $\begin{array}{l}\text { emission reduction, energy saving, job } \\
\text { creation and local participation }\end{array}$ \\
\hline $\begin{array}{l}\text { peat land } \\
\text { 'futures' in } \\
\text { German } \\
\text { federal states }\end{array}$ & $\begin{array}{l}\text { financing land use change for } \\
\text { conservation through innovative } \\
\text { emission offsetting certificates }\end{array}$ & $\begin{array}{l}\text { emission reduction, peat land } \\
\text { conservation, land owner } \\
\text { compensation }\end{array}$ \\
\hline $\begin{array}{l}\text { eco-industrial } \\
\text { park in } \\
\text { Dunkirk, } \\
\text { France }\end{array}$ & $\begin{array}{l}\text { building networks and support } \\
\text { capacity building among private actors }\end{array}$ & $\begin{array}{l}\text { circular resource flows and resource } \\
\text { efficiency and local value added }\end{array}$ \\
\hline $\begin{array}{l}\text { eco-wise } \\
\text { region in } \\
\text { Jyväskylä, } \\
\text { Finland }\end{array}$ & $\begin{array}{l}\text { public investment in research, } \\
\text { information and monitoring tools }\end{array}$ & $\begin{array}{l}\text { emissions and material loss } \\
\text { reductions, ecological footprint and } \\
\text { experienced well-being }\end{array}$ \\
\hline
\end{tabular}


Author-produced version of the article published in Journal of Cleaner Production, 2016, N¹35, p.426-434

The original publication is available at http://www.sciencedirect.com

Doi: 10.1016/j.jclepro.2016.06.123

We selected the cases from a projects' case study portfolio (Pitkänen et al., 2016) in order to present exemplary government interventions. The analysed policies range from more direct measures such as regulation through government's own activities in terms of public procurement and (infrastructure) investment, to indirect measures such as setting incentives, and "softer" measures such as supporting capacity building and information and monitoring tools (for an overview, see Allen, 2012; UNEP, 2014a). For each case, we provide, first, some background information. Second, we employ our conceptual institutional system model of innovation by analysing the effect of the respective policy on markets, organisations, and innovators. Third, we elaborate on the transformational success towards a green economy (or otherwise) by considering both social equity and environmental indicators and - where applicable - discuss the case's limitations in offsetting losses in one of the dimensions with gains in the other. Table 1 gives an overview of the case studies' operationalization of main types of government intervention and green economy transitions indicators ${ }^{6}$.

\subsection{Case studies - innovations and transformations towards a green economy}

\subsubsection{Government regulation and market interventions}

The most direct means of enabling innovation towards a green economy transition is to regulate people's economic behaviour through a set of legal provisions and standards that either permit or prohibit a particular type of action. A prominent example of such direct regulation is the energy transition in Germany (German: Energiewende) which has been variously characterized as a regime shift (Strunz, 2014), a green industrial policy (Pegels and Lütkenhorst, 2014), and a sustainability project (Gawel et al., 2014). The German energy transition has strong elements of direct government regulation but is also based on market intervention, achieved through a set of incentives (subsidies) for renewable energies.

Background: Germany's energy transition can at least be retraced to the early 1980s (Strunz, 2014). Over the years, this vision has become official policy: the 1990s and 2000s saw the introduction and extension of effective support policies for renewables (Strunz, 2014). The respective policies led to a change in market conditions and thus economic viability of energy production technology. While nuclear energy is being phased out (target year 2022), fossil fuels are on a longer transition path, but both are being ruled out in the long term. Contrastingly, renewable energy is being heavily promoted through feed-in tariffs (Gawel et al., 2014; Pegels and Lütkenhorst, 2014).

Innovations: The German energy transition encompasses changes at different system levels, ranging from innovations in niche renewable energy technologies (Verbong and Geels, 2007), located at the actor and organization level, to regime shifts (Strunz, 2014) at the market and governance level. Although the regulatory intervention created favourable conditions for renewable innovations, entrepreneurial pioneers have been at the forefront of renewable energy technology development long before the governance regime shift (Pegels and Lütkenhorst, 2014). Parallel to this, a social movement and an enabling social network had also evolved - the Green party in Germany has its roots in that very movement (Strunz, 2014). However, the recent large-scale dissemination of renewables has essentially been fostered by state intervention in form of policies ruling out nuclear

\footnotetext{
${ }^{6}$ As a general set of indicators for a assessing the transformative effect of a green economy transitioning project may serve the sustainable development goals - provided that a gain in an environmental dimension does not incur a loss at a social dimension (see section 2.2).
} 
Author-produced version of the article published in Journal of Cleaner Production, 2016, N¹35, p.426-434

The original publication is available at http://www.sciencedirect.com

Doi: 10.1016/j.jclepro.2016.06.123

and fossil energy and supporting the competitiveness of innovative solutions in the German energy sector. The governmental market intervention has induced a systemic change in production patterns and has enabled renewable energy businesses to succeed in a relatively oligopolistic market structure. It has provided an opportunity to "boost innovative capabilities and create employment opportunities in future growth markets" (Pegels and Lütkenhorst, 2014, p. 522).

Transformative Effects: The German energy transition is a suitable example of moving the action space outwards, improving both societal and environmental conditions, enabling new market segments elements by means of subsidies and disabling nuclear and fossil fuel based energy. It has led to an increase in electricity generation from renewable energy sources and thereby to a reduction in greenhouse gases (see Creutzig et al., 2014). In addition, it is creating new business and employment opportunities (Smith Stegen and Seel, 2013). Decentralized and, also in some cases, remunicipalized energy providers often benefit from the transition (Moss et al., 2014). There are, of course, businesses that face difficulties due to the energy transition - not least the large energy companies with their locked-in business models - but there are also a range of financial exceptions for energy intense industries to counteract negative consequences for the economy (Gawel et al., 2014). The transition has also led to increasing costs for electricity consumption, and these need to be offset by means of energy efficiency measures in order to avoid burdening low-income groups with unaffordable costs (Gawel et al., 2014). Hence, the German energy transition is a highly promising candidate for successful systemic green economy innovation - facilitated substantially by government regulation and market intervention and leading to large-scale investments and economic stimuli for actors, organisations and markets.

\subsubsection{Public procurement $\&$ infrastructure investment}

The government influences both society, e.g. through employment and public procurement, and the environment, e.g. through infrastructure development (Allen, 2012; UNEP, 2014a). In particular, public spending can influence green innovation both from the supply and the demand side (Edler and Uyarra, 2012; Otter and Weber, 2015). For our analysis of green public procurement and infrastructure investment we focus on the case of HINKU, a network of carbon neutral municipalities in Finland (SYKE, 2015).

Background: 24 small to medium Finnish municipalities have committed to a reduction of greenhouse gas emissions in the HINKU network. The project began in 2008 with five municipalities along with several businesses and local residents and now comprises 31 municipalities. The adoption of climate-friendly technologies in the sectors of energy efficiency, renewable energy, housing and transport is being done to create "win-win-win solutions" for the economy, society and the environment (SYKE, 2013).

Innovations: The project originated from a business initiative focused on social responsibility (SYKE, 2013): it was a group of businesses leaders with innovative ideas about energy saving that initiated the process at the actor level. These (new) businesses organized through an entrepreneurial network and asked SYKE, the Finnish Environment Agency for coordination - creating a social organisation to reduce risks of the venture. Hence, the process of coordinating activities within a broader network of businesses, municipalities and residents was an important facilitating element to survive under current market condition. It resulted in the development of a dynamic regional innovation system based on strong horizontal cooperation. An active regional government commitment created a demand and thus market opportunities for energy efficient products, reduced entrepreneurial risk and contributed to local learning regarding energy saving (Heiskanen et al., 
Author-produced version of the article published in Journal of Cleaner Production, 2016, N¹35, p.426-434

The original publication is available at http://www.sciencedirect.com

Doi: 10.1016/j.jclepro.2016.06.123

2015). The initiative is hence based on individual and entrepreneurial innovation but supported and facilitated through pro-active municipal administrative involvement in terms of public procurement and investment which in turn had positive knock-on effects on other businesses, residents and other municipalities.

Transformative Effects: At the beginning of the process, coordinated action and broader societal and administrative support helped to harvest the low-hanging fruits of real business cases that are environmental friendly. The municipalities' decision to reduce their emissions and invest in renewable energy generation, public building insulation and electric vehicle infrastructure has triggered a wider, participatory process that is gaining momentum. However, so far only relatively small and a few medium sized municipalities are involved in the project. It can therefore be seen as an intermediate step towards a broad-scale systemic transformation. The network is still growing and is beginning to include larger municipalities (SYKE, 2015, 2013).

\subsubsection{Getting the incentives right or having second-best options}

Private land users make land-use decisions on the basis of land quality and with a view to the wider economic and market conditions. For a successful transition to a green economy, therefore, it is important to consider the incentives inherent in the current economic system and to change them in a way that will facilitate both social and environmental gains (TEEB, 2011; UNEP, 2014a, 2011a). For our analysis of market incentives that lead in this direction we chose to look at an innovative financing instrument for rewetting and restoring peat lands in Germany known as "MoorFutures" ("peat land futures").

Background: When carbon-rich soils and peat lands are drained and used for large-scale agriculture they turn from a carbon sink into a carbon source by emitting substantial volumes of greenhouse gases (Bonn et al., 2014). To resolve this situation the German states of MecklenburgWestern Pomerania, Brandenburg and Schleswig-Holstein have begun to issue certificates with a protected trademark for the emissions reductions achieved by restoring peat lands on the voluntary carbon market.

Innovations: In this case the state (or rather a particular person in state ministries) of Mecklenburg-Western Pomerania has come up with the innovative idea for financing peatland restoration and financing conservation through private and voluntary compensation payments. The state actors collaborated with scientists to reduce the uncertainty regarding valid assessments building a network or a social 'organisation'. Furthermore, the official government issuance increased the credibility of the newly designed certificate for the voluntary carbon market. The certificates create the necessary investment volume, raise awareness about peat lands, and - as a second best solution - provide a correction to harmful incentives in agricultural production (cf. Bonn et al., 2014; TEEB DE, 2015).

Transformative Effects: Current agricultural practices are interconnected with the incentives created by the subsidies for biogas production to achieve the German energy transition. It is economically more viable, for example, for private land users to plant corn for biomass and biogas production and to have pastures for dairy cattle. Such cross-sectorial trade-offs have to be taken into account when assessing the success of a green economy transition (TEEB DE, 2015). The "brown", climate unfriendly practices of agriculture should be (financially) constrained, while environmentally friendly and site-adequate farming practices need to be (financially) encouraged. The "Moorfutures" certificates are thus a second-best option to leverage the required finance to compensate private land users and to provide a correction to the external effects that are a consequence of harmful 
Author-produced version of the article published in Journal of Cleaner Production, 2016, N¹35, p.426-434

The original publication is available at http://www.sciencedirect.com

Doi: 10.1016/j.jclepro.2016.06.123

incentives. As such, the peatland futures do not constitute a systemic transformation towards a green economy but an important element of it by reducing environmental harm.

\subsubsection{Building networks and support capacity building}

For a transition towards a green economy of the existing (market) system, new production structures and thus knowledge and sufficient networking capacities are required. The industrial ecology approach in Dunkirk, France aims to close the loop and create a circular economy production patterns increase the efficiency of resource use (Varlet, 2012).

Background: In 2001, a local association, Economie et Ecologie Partenaires dans l'Action locale (Ecopal), was created with the financial support of regional and local authorities to develop industrial ecology initiatives in harbour area of Dunkirk and currently counts more than 200 members. Ecopal supports flow substitutions between partners by facilitating information sharing on current practices and processes among SMEs and big firms (Beaurain and Varlet, 2014).

Innovations: In this case, the innovation is basically the creation of a club through local government support that turned into a functioning association of an eco-industrial network. A single firm cannot achieve such system transformation of inter-firm resource flows on his own but hinges on a network of collaborating businesses. The creation of Ecopal is such an example, where a regional firm network was started through the active involvement and funding of local government (Varlet, 2012). The creation of the network, the exchange of information and the building of collaborative capacities resulted in an innovative regional organization that creates its own business opportunities, and thereby local 'markets' for the exchange of resources.

Transformative Effects: On a regional scale the creation of Ecopal has created a transition of how firms cooperate in order to close resource flow loops. It does, however, not yet represent a largerscale a green economy transition. Although there are already some similar local networks, as such Ecopal is an innovation that has yet to be adapted in other regions in order to facilitate a larger scale transition (Beaurain and Varlet, 2014). Similar to the facilitating role of the local government for the creation of the Dunkerque network, national governments may play a vital role in creating a network of several of such local organisations. The EU circular economy strategy may even require a transnational network of eco-industrial parks.

\subsubsection{Research, information and monitoring tools}

Sustainability strategies require information and monitoring tools to measure their success (UNEP, 2014b, 2014c). As an example we elaborate on a resource effciency project in Jyväskylä, Finland.

Background: In 2013, the Finnish Innovation Fund Sitra launched the "resource-wise region" project (Sitra, 2015). The project develops an assessment tool for regional resource efficiency. It is being conducted in cooperation with local residents, companies and organizations.

Innovations: The innovator in this case is the city of Jyväskylä, which has been willing to take the risk and invest in a resource efficiency assessment approach with a replicable measurement process. The city administration has been supported financially by Sitra in order to create a show case for other Finnish cities. This support enhanced risk coping willingness and capability of Jyväskylä. The implemented measures created some new market opportunities, i.e. at the local scale through public demand for energy and resource savings. The local networking process involved the city, local businesses, citizens and other stakeholders, including local NGOs. A wide variety of measures have been implemented in Jyväskylä, including a set of 14 strategic experiments testing the concepts of 
Author-produced version of the article published in Journal of Cleaner Production, 2016, N¹35, p.426-434

The original publication is available at http://www.sciencedirect.com

Doi: 10.1016/j.jclepro.2016.06.123

resource efficiency, e.g. free public transport, sharing leftover food in schools and improving resource efficiency in homes (Mattinen et al., 2014).

Transformative Effects: With regard to the potential for triggering a transition to a green economy, a set of indicators including four key indicators for measuring "resource wisdom" has been developed (emissions per inhabitant, material losses, ecological footprint, and experienced wellbeing). Hence, the transformative effects of the experimental implementations can be assessed through the developed measurements. Currently, the operating model has been expanded to three other cities in Finland, and a network of Finnish sustainable communities (FISU) was launched in June 2015.

\section{Summary and concluding remarks}

In this paper we have sought to contribute in three ways to conceptualizing the transition towards a green economy:

1. By extending the system innovation models of Schumpeter (1928) and Röpke (1977) we have developed a framework that explains the emergence of (sustainable) innovations on the basis of five interlinked factors. In this model, innovations take place with an actor at the core, who is embedded within an organization that helps or hinders the task of managing the risks associated with the innovation. The organization itself is located within wider market structures that are defined by the rules of an overarching governance system within the outermost planetary system boundaries. Of these five system levels governance system strongly influences its subsystems by imposing the rules of the game and setting the institutions that may safe-guard bio-physical limits of system Earth. Within the governance system the government has a central role in formally creating rules and incentives within the system and thus steering societal development.

2. To assess whether the transition to a green economy is successful or not, we have presented a schematic bi-dimensional model that infers two minimum standards from the normative implications of the concept: neither the natural nor the social dimension should be adversely affected. We hypothesize furthermore that allowing for "true" Pareto improvements is not enough but that limiting the action space at the least socially and environmentally friendly end, that of the "brown" economy, is required as well.

3. We have illustrated the role and potential of diverse government interventions, namely (i) regulation, (ii) public procurement and investment, (iii) setting incentives and raising revenues, (iv) network and capacity building, and (v) monitoring processes. We have provided evidence from five case studies across Europe. In this respect, we complemented our by applying conceptual reasoning to an empirical context.

How to replicate and upscale successful implementations of local or even national green economy transitions remains a question for future research. However, it is important to note that the green economy is an overarching concept; any policy aimed at achieving it must therefore also take account of - and wherever possible internalize - (unintended) cross-sector, cross-nation, cross-policy trade-offs. Policy mixes regarding green economy transitions have thus to be designed with due care and precision in order to help risk coping of individual inventors, support societal organisation and change the market towards more favourable conditions. Then, green economy transitions may indeed materialise systemic societal sustainability transformations. 
Author-produced version of the article published in Journal of Cleaner Production, 2016, N¹35, p.426-434

The original publication is available at http://www.sciencedirect.com

Doi: 10.1016/j.jclepro.2016.06.123

\section{Acknowledgements}

This research originates from the Partnership for European Environmental Research (PEER) Green Economy project and the manuscript benefited from a language check by Kathleen Cross. We gratefully acknowledge the helpful and constructive feedback from the editor in charge, Frank Boons, and two anonymous referees.

\section{References}

Allen, C., 2012. Exploring green economy policies and international experience with national strategies, A Guidebook to the Green Economy, Issue 2. UN Division for Sustainable Development, UNDESA, New York.

Allen, C., Jussila, R., 2013. A guide to international green economy initiatives, A Guidebook to the Green Economy, Issue 4. UN Division for Sustainable Development, UNDESA, New York.

Barbier, E., 2011. The policy challenges for green economy and sustainable economic development. Nat. Resour. Forum 35, 233-245. doi:10.1111/j.1477-8947.2011.01397.x

Barbier, E., 2012. The Green Economy Post Rio+20. Science 338, 887-888.

Barbier, E.B., Markandya, A., 2013. A new blueprint for a Green Economy. Routledge, New York.

Beaurain, C., Varlet, D., 2014. Quelques pistes de réflexion pour une approche pragmatiste de l'écologie industrielle : l'exemple de l'agglomération dunkerquoise. Développement durable Territ. 5, 1-25.

Bonn, A., Reed, M.S., Evans, C.D., Joosten, H., Bain, C., Farmer, J., Emmer, I., Couwenberg, J., Moxey, A., Artz, R., Tanneberger, F., Unger, M. Von, Smyth, M., Birnie, D., 2014. Investing in nature : Developing ecosystem service markets for peatland restoration. Ecosyst. Serv. 9, 54-65. doi:10.1016/j.ecoser.2014.06.011

Borrás, S., Edquist, C., 2013. The Choice of Innovation Policy Instruments. Technol. Forecast. Soc. 80, 15131522. doi:10.1016/j.techfore.2013.03.002

Brown, G., Kraftl, P., Pickerill, J., Upton, C., 2012. Holding the future together: Towards a theorisation of the spaces and times of transition. Environ. Plan. A 44, 1607-1623. doi:10.1068/a44608

Cooke, P., 2015. Green Governance and Green Clusters: Regional and National Policies for the Climate Change Challenge of Central \& Eastern Europe. J. Open Innov. 1, 1-17. doi:10.1186/s40852-015-0002-z

Costanza, R., Alperovitz, G., Daly, H.E., Farley, J., Franco, C., Jackson, T., Kubiszewski, I., Schor, J., Victor, P., 2012. Building a Sustainable and Desirable Economy-in-Society-in-Nature. United Nations Division for Sustainable Development, New York.

Creutzig, F., Goldschmidt, J.C., Lehmann, P., Schmid, E., Von Blücher, F., Breyer, C., Fernandez, B., Jakob, M., Knopf, B., Lohrey, S., Susca, T., Wiegandt, K., 2014. Catching two European birds with one renewable stone: Mitigating climate change and Eurozone crisis by an energy transition. Renew. Sustain. Energy Rev. 38, 1015-1028. doi:10.1016/j.rser.2014.07.028

Daly, H.E., Farley, J., 2011. Ecological Economics: Principles and Applications, 2nd ed. Island Press.

Dolata, U., 2011. Radical Change as Gradual Transformation. Characteristics and Variants of Socio-technical Transitions, SOI Discussion Paper No. 2011-03. Institute for Social Sciences, University of Stuttgart.

Edler, J., Uyarra, E., 2012. Public Procurement of Innovation, in: Brown, L., Osborne, S. (eds.), The Handbook of Innovation and Change in Public Sector Sevices. Edward Elgar, Cheltenham.

Edquist, C., 1997. Systems of Innovation Approaches - their Emergence and Characteristics, in: Edquist, C. (Ed.), Systems of Innovation: Technologies, Institutions and Organizations. Pinter Publishers/Cassel Academic:London, pp. 41-60.

Edquist, C., 2001. The Systems of Innovation Approach and Innovation Policy: An Account of the State of the Art. Lead paper presented at the DRUID conference. [online] URL http://citeseerx.ist.psu.edu/viewdoc/download?doi=10.1.1.336.4438\&rep=rep1\&type=pdf.

EU, 2015. Closing the loop - An EU action plan for the Circular Economy. COM/2015/0614 final.

Flanagan, K., Uyarra, E., Laranja, M., 2011. Reconceptualising the "policy mix" for Innovation. Res. Policy 40, 702-713.

Freeman, C., 1995. The National System of Innovation in Historical Perspective. Cambridge J. Econ. 18, 5-24.

Gawel, E., Lehmann, P., Korte, K., Strunz, S., Bovet, J., Köck, W., Massier, P., Löschel, A., Schober, D., Ohlhorst, D., Tews, K., Schreurs, M., Reeg, M., Wassermann, S., 2014. The future of the energy transition in Germany. Energy. Sustain. Soc. 4, 15. doi:10.1186/s13705-014-0015-7

Geels, F.W., 2004. From sectoral systems of innovation to socio-technical systems: Insights about dynamics and change from sociology and institutional theory. Res. Policy 33, 897-920. doi:10.1016/j.respol.2004.01.015

Geels, F.W., 2011. The multi-level perspective on sustainability transitions: Responses to seven criticisms. Environ. Innov. Soc. Transitions 1, 24-40. doi:10.1016/j.eist.2011.02.002 
Author-produced version of the article published in Journal of Cleaner Production, 2016, N¹35, p.426-434

The original publication is available at http://www.sciencedirect.com

Doi: 10.1016/j.jclepro.2016.06.123

Geels, F.W., 2014. Regime Resistance against Low-Carbon Transitions: Introducing Politics and Power into the Multi-Level Perspective. Theory, Cult. Soc. 0263276414531627-. doi:10.1177/0263276414531627

Heiskanen, E., Jalas, M., Rinkinen, J., Tainio, P., 2015. The local community as a "low-carbon lab": Promises and perils. Environ. Innov. Soc. Transitions 14, 149-164. doi:10.1016/j.eist.2014.08.001

Hoogma, R., Kemp, R., Schot, J., Truffer, B., 2002. Experimenting for Sustainable Transport: The Approach of Strategic Niche Management. Spon Press, London.

Krause, F., Bossel, H., Müller-Reißmann, K.-F., 1980. Energiewende - Wachstum und Wohlstand ohne Erdöl und Uran. Fischer, Frankfurt am Main.

Lehtola, V., Ståhle, P., 2014. Societal innovation at the interface of the state and civil society. Innov. Eur. J. Soc. Sci. Res. 27, 152-174. doi:10.1080/13511610.2014.863995

Loiseau, E., Saikku, L., Antikainen, R., Leskinen, P., Pitkänen, K., Droste, N., Hansjürgens, B., Kuikman, P., Thomsen, M., 2016. Green Economy and related concepts: an overview. Submitted to J. Clean. Prod. - this issue.

Loorbach, D., 2010. Transition Management for Sustainable Development: A Prescriptive, Complexity-Based Governance Framework. Governance 23, 161-183. doi:10.1111/j.1468-0491.2009.01471.x

Markard, J., Raven, R., Truffer, B., 2012. Sustainability transitions: An emerging field of research and its prospects. Res. Policy 41, 955-967. doi:10.1016/j.respol.2012.02.013

Markard, J., Truffer, B., 2008. Technological innovation systems and the multi-level perspective: Towards an integrated framework. Res. Policy 37, 596-615. doi:10.1016/j.respol.2008.01.004

Mattinen, M.K., Nissinen, A., Hyysalo, S., Juntunen, J.K., 2014. Energy Use and Greenhouse Gas Emissions of Air-Source Heat Pump and Innovative Ground-Source Air Heat Pump in a Cold Climate. J. Ind. Ecol. 19, 6170. doi:10.1111/jiec.12166

Lundvall, B.-A., (Ed.), 1992. National Innovation Systems: Towards a Theory of Innovation and Interacting Learning.Pinter Publishers, London.

Moss, T., Becker, S., Naumann, M., 2014. Whose energy transition is it, anyway? Organisation and ownership of the Energiewende in villages, cities and regions. Local Environ. 1-17. doi:10.1080/13549839.2014.915799

Otter, N., Weber, M., 2015. Determinants of Public Sector Innovation: The Example of Capacity Development in Public Procurement. International Public Administration Review 13, 9-27.

Pearce, D., Markandya, A., Barbier, E., 1989. Blueprint for a green economy. Earthscan, London.

Pegels, A., Lütkenhorst, W., 2014. Is Germany's energy transition a case of successful green industrial policy? Contrasting wind and solar PV. Energy Policy 74, 522-534. doi:10.1016/j.enpol.2014.06.031

Pitkänen, K., Antikainen, R., Droste, N., Loiseau, E., Saikku, L., Aissani, L., Hansjürgens, B., Kuikman, P., Leskinen, P., Thomsen, M., Aissani, L. 2016. Implementing green economy in practice: Learnings from European case studies. Submitt. to J. Clean. Prod. - this issue.

Pretty, J., Brett, C., Gee, D., Hine, R., Mason, C., Morison, J., Rayment, M., Bijl, G. Van Der, Dobbs, T., 2010. Policy Challenges and Priorities for Internalizing the Externalities of Modern Agriculture. J. Environ. Plan. Manag. 44, 263-283. doi:10.1080/09640560123782

Rockström, J., Steffen, W., Noone, K., Persson, Å., Chapin, F.S.I., Lambin, E., Lenton, T.M., Scheffer, M., Folke, C., Schellnhuber, H.J., Nykvist, B., Wit, C.A. de, Hughes, T., Leeuw, S. van der, Rodhe, H., Sörlin, S., Snyder, P.K., Costanza, R., Svedin, U., Falkenmark, M., Karlberg, L., Corell, R.W., Fabry, V.J., Hansen, J., Walker, B., Liverman, D., Richardson, K., Crutzen, P., Foley, J., 2009. Planetary boundaries: exploring the safe operating space for humanity. Ecol. Soc. 14, 32. [online] URL: http://www.ecologyandsociety.org/vol14/iss2/art32

Röpke, J., 1977. Die Strategie der Innovation. Mohr, Tübingen.

Rotmans, J., Kemp, R., van Asselt, M., 2001. More evolution than revolution: transition management in public policy. foresight 3, 15-31. doi:10.1108/14636690710816471

Schot, J., Geels, F.W., 2008. Strategic niche management and sustainable innovation journeys: theory, findings, research agenda, and policy. Technol. Anal. Strateg. Manag. 20, 537-554. doi:10.1080/09537320802292651

Schumpeter, J.A., 1928. Der Unternehmer in der Volkswirtschaft von heute, in: Harms, B. (Ed.), Strukturwandlungen Der Deutschen Volkswirtschaft. Reimar Hobbing, Berlin, pp. 303-326.

Scott, W.R., 2008. Approaching adulthood: The maturing of institutional theory. Theory Soc. 37, 427-442. doi:10.1007/s11186-008-9067-z

Sitra, 2015. Resource wisdom [WWW Document]. URL http://www.sitra.fi/en/ecology/resource-wisdom (accessed 06.01.15).

Smith, A., 2007. Translating sustainabilities between green niches and socio-technical regimes. Technol. Anal. Strateg. Manag. 19, 427-450. doi:10.1080/09537320701403334 
Author-produced version of the article published in Journal of Cleaner Production, 2016, N¹35, p.426-434

The original publication is available at http://www.sciencedirect.com

Doi: 10.1016/j.jclepro.2016.06.123

Smith, K., 2000. Innovation as a Systemic Phenomenon: Rethinking the Role of Policy. Enterp. Innov. Manag. Stud. 1, 73-102. doi:10.1080/146324400363536

Smith Stegen, K., Seel, M., 2013. The winds of change: How wind firms assess Germany's energy transition. Energy Policy 61, 1481-1489. doi:10.1016/j.enpol.2013.06.130

Steffen, W., Richardson, K., Rockström, J., Cornell, S., Fetzer, I., Bennett, E., Biggs, R., Carpenter, S.R., de Wit, C. a., Folke, C., Mace, G., Persson, L.M., Veerabhadran, R., Reyers, B., Sörlin, S., 2015. Planetary Boundaries: Guiding human development on a changing planet. Science (80-. ). 347. doi:10.1126/science.1259855

Strunz, S., 2014. The German energy transition as a regime shift. Ecol. Econ. 100, 150-158. doi:10.1016/j.ecolecon.2014.01.019

Swyngedouw, E., 2005. Governance innovation and the citizen: The Janus face of governance-beyond-the-state. Urban Stud. 42, 1991-2006. doi:10.1080/00420980500279869

SYKE, 2013. Towards Carbon Neutral Municipalities - An Innovative Finnish Approach. Helsinki.

SYKE, 2015. HINKU-foorumi [WWW Document]. URL http://www.hinku-foorumi.fi/en-US (accessed 30.05.15).

TEEB, 2011. The Economics of Ecosystems and Biodiversity for National and International Policy Makers. Earthscan, London and Washington.

TEEB DE - Natural Capital Germany, 2015. Natural Capital and Climate Policy: Synergies and Conflicts. Tecnical University Berlin, Helmholtz Centre for Environmental Research - UFZ, Berlin, Leipzig.

UN, 2012. The future we want [WWW Document]. URL http://www.un.org/en/sustainablefuture/ (accessed 15.06.15).

UN, 2015. Transforming our world: the 2030 Agenda for Sustainable Development. Resolution 70/1 adopted by the General Assembly on 25 September 2015

UNEP, 2010. Green Economy Developing Countries Success Stories. United Nations Environment Programme, Geneva.

UNEP, 2011. Towards a Green Economy: Pathways to Sustainable Development and Poverty Eradication. United Nations Environment Programme, Nairobi.

UNEP, 2014a. A Guidance Manual for Green Economy Policy Assessment. United Nations Environment Programme, Nairobi.

UNEP, 2014b. Using indicators for green economy policymaking. United Nations Environment Programme, Nairobi.

UNEP, 2014c. Using models for Green Economy Policymaking. United Nations Environment Programme, Nairobi.

Uyarra, E. (2010): What is Evolutionary about 'Regional Systems of Innovation'? Implications for Regional Policy. J. Evol. Econ. 20, 115-137.doi:10.1007/s00191-009-0135-y

Varlet, D., 2012. Enjeux, potentialités, contraintes de l'écologie industrielle. Le cas de Dunkerque. Doctoral Thesis. Université du Littoral Côte d'Opale, Dunkerque.

Verbong, G., Geels, F., 2007. The ongoing energy transition: Lessons from a socio-technical, multi-level analysis of the Dutch electricity system (1960-2004). Energy Policy 35, 1025-1037. doi:10.1016/j.enpol.2006.02.010

Weber, A., 2014. How are public transaction costs in regional agri-environmental scheme delivery influenced by EU regulations? J. Environ. Plan. Manag. 57, 937-959. doi:10.1080/09640568.2013.776950 